\title{
Comparative Study of Under Nutrition among Government and Private School Children of Suraram Village, Hyderabad
} (Original Article)

\author{
Authors \\ Dr K. Harika Priyadarshini ${ }^{1}$, Dr Jetty Jerusha ${ }^{2}$, Dr Malleswaramma ${ }^{3}$ \\ Dr N.VijaySam ${ }^{4}$, B.Navya ${ }^{5}$ \\ ${ }^{1,2}$ Assistant Professors, ${ }^{3}$ Head of the Department, ${ }^{4} 2^{\text {nd }}$ year MBBS Student, Department of Physiology, \\ Guntur Medical College, Guntur, A.P, India. \\ ${ }^{5}$ Sr.Officer, Life Science Incubator, IKP, Hyderabad, India \\ Corresponding Author \\ Dr Harika Priyadarshini \\ Assistant Professor, Department of Physiology, Guntur Medical College, Guntur, AP \\ Email id:dr.harika03@gmail.com
}

\begin{abstract}
The present study was carried out to find out growth pattern in school children from different socioeconomic background of Government \& Private school children. Materials \&Methods: The study was conducted in both boys and girl subjects $(n=360)$, Aged between 5-10 years, who are of different socio economic status and the parameters selected for the study are Height, Weight, Body Mass Index, Chest Circumference. Case group involves Government school children and Control group involves Private school children, who were selected randomly. History of socioeconomic status is also assessed by taking family history. Results \& Discussion: In this study we found that Height, Weight, Body Mass Index, Chest Circumference of Government school children has lesser value compared to Private school children. Conclusion: This study mainly focuses on malnutrition and helps in identification of Prevalence of malnutrition highlights the significance of developing integrated child illness management and strengthening nutrition intervention programs

Keywords-Under nutrition, Height, Weight, Body Mass Index, Chest Circumference.
\end{abstract}

\section{Introduction}

Growth assessment is the single measurement that best defines the nutritional and health status of the children, because nutritional problems affect child growth $^{(1)}$. Malnutrition is defined as failure to consume adequate energy, protein and micronutrients to meet the basic requirement for body maintenance, growth and development. Malnutrition is highly prevalent due to poverty and lack of awareness and literacy. Nutritional problem results due to imbalance between the needs of the body and intake of the nutrients, or severe and repeated infection or a combination of two ${ }^{(2)}$. Being most vulnerable segment of the community the school going children are at greatest risk of malnutrition, since it is their growing period which demands high intake of proteins and calories. Unclean food and utensils, 
dirty hands, unsafe water which are the common risk for the production of protein energy malnutrition ${ }^{(3)}$. Malnourished children may suffer from numerous associated complications. Malnourishment in young children is conventionally determined through measurement of height, weight and arm circumference for age, head circumference for age. Overall both girls and boys have similar prevalence of malnutrition. Prevalence of under nutrition is higher in rural areas than in urban ${ }^{(4)}$. Recommendations based on 'My Pyramid' are within 5 Food groups (grains, vegetables, fruits, milk, meat and beans plus oils with the general recommendations to eat, overtime, a variety of foods within each food groups. 'My Pyramid' offers recommendation for physical activity to achieve a healthy energy balance. 'My Pyramid' offers are helpful and customer friendly tool to council families and optimal eating plants for short and long term health ${ }^{(5)}$.

\section{Materials \& Methods}

The present study was conducted in $(n=360)$, their age ranging from 5 to 10 years. Subjects were taken from of Central Public school and private school of Suraram village, Hyderabad. Two rural schools were selected by simple random saming method. Ethical Committee Clearance was obtained from the Institutional Ethical Clearance Committee. Prior to the study, consent was taken from the school authority and parents of the school children to carry the research work and each subject was informed in detail of the objectives and aim of the research protocol and methods to be used. The data was collected using A PREDESIGNED AND PRE TESTED proforma. Prior to the study, each subject was informed in detail of its objectives and the aim of the research protocol and methods to be used. Their consent was obtained Anthropometry offers a reliable method to assess the nutritional status of the children. Anthropometry is the single most universally applicable, inexpensive and noninvasive method available to assess the size, proportion and composition of human body. WHO has recommended various indices based on anthropometry to evaluate the nutritional status of chilDREN. SINCE IT IS A NONINVASIVE technique and causes little discomfort to the subjects. WHO child growth standards, were used to classify malnutrition. Data thus generated was analysed and appropriate tables were generated. The anthropometry data have been used to track growth and weight trends in the population. The anthropometric data for children reflect general health status and dietary adequacy and are used to track trends in growth and development over time.

\section{Experimental Protocol}

The study constitutes estimation of height, weight, body mass index and chest circumference Age was recorded from school records. Portable stadiometer is used for measuring height). For the measurement of standing height, the child was asked to stand with his/her back against the board. Standing height for each child was measured by making the child stand barefoot with heels, buttocks and shoulders touching the vertical surface and head in the Frankfurt plane. The back, scapulae and buttocks are in contact with the vertical board if possible, or whichever part of the body touches the board first.

The weight was measured barefooted and the child is asked to step up backwards onto the scale and stand still over the center of the scale with body weight evenly distributed between both feet. The child's arms should be hanging freely by the sides of the body, with palms facing the thighs. The child should hold his/her head up, and face forward. Age was recorded from school records.

Chest circumference - It was measured at the level of fifth intercostal space during inspiration and expiration.

\section{Statistical Methods}

Data were reported as mean and standard deviation [mean $\pm \mathrm{SD}$ ]. Means were compared between two groups by un paired 't' test. A p value of $<0.05$ was considered statistically 
significant. used to find the significance of study parameters Descriptive statistical analysis was carried out in the present study. Results on continuous measurements were presented on Mean \pm SD. Student ' $\mathrm{t}$ ' test was between two groups.

\section{Results}

Three hundred and sixty students (360) of different age groups ranging from 5-10years of age were examined using Height, Weight, body mass index and chest circumference as a parameter. Out of 360 students, 180 students were from government School and 180 students were from private School. Using abovedata, height, weight, body mass index and chest circumference of Government and private school students were measured and the findings in different age groups were tabulated. The mean and standard deviation of each parameter was calculated.

According to the present study as depicted in Table 1, the mean height of the private school was higher than the government school which was $124.93 \mathrm{~cm}$ and the difference has been found to be statistically highly significant. The mean weight of the private school was more than the government school which was $23.82 \mathrm{~kg}$ and the difference has been found to be statistically highly significant. The mean body mass index of the private school was higher than the government school which was 19.04 and the difference has been found to be statistically highly significant. The mean Chest Circumferences of the private school was higher than the government school which was $49.2 \mathrm{~cm}$ and the difference has been found to be statistically highly significant.
Table 1: Comparision of parameters of Govt and Private School

\begin{tabular}{|l|l|l|l|l|}
\hline Parametes & $\begin{array}{l}\text { Govt } \\
\text { School } \\
\text { mean } \pm \text { SD }\end{array}$ & $\begin{array}{l}\text { Private } \\
\text { School } \\
\text { mean } \pm \text { SD }\end{array}$ & $\begin{array}{l}\text { T } \\
\text { Value }\end{array}$ & $\begin{array}{l}\text { P } \\
\text { Value }\end{array}$ \\
\hline $\begin{array}{l}\text { Height in } \\
\text { cms }\end{array}$ & $\begin{array}{l}114.24 \pm 10 . \\
29\end{array}$ & $\begin{array}{l}124.93 \pm \\
9.75\end{array}$ & 10.11 & 0.001 \\
\hline $\begin{array}{l}\text { Weight in } \\
\text { kgs }\end{array}$ & $17.68 \pm 3.64$ & $\begin{array}{l}23.82 \pm \\
4.60\end{array}$ & 13.99 & 0.001 \\
\hline $\begin{array}{l}\text { BMI } \\
\text { BMest } \\
\text { circumfer } \\
\text { ence }\end{array}$ & $45.85 \pm 6.37$ & $49.2 \pm 2.41$ & 6.59 & 0.001 \\
\hline
\end{tabular}

As shown in Table 2, the mean height of the private school was increased from $111.39 \mathrm{~cm}$ to $138.96 \mathrm{~cm}$ and the mean height of government school was increased from $104.52 \mathrm{~cm}$ to $128.86 \mathrm{~cm}$. The mean height of private school was found to be more than mean height of government school in each age group. Results found to be statistically highly significant.

Table 2: Comparison of height (in cms) of Govt and Private School children

\begin{tabular}{|c|l|l|l|l|}
\hline \multirow{2}{*}{$\begin{array}{l}\text { Age } \\
\text { in } \\
\text { years }\end{array}$} & \multicolumn{2}{|l|}{$\begin{array}{l}\text { Height of children ( mean } \\
\pm \mathrm{SD})\end{array}$} & \multicolumn{1}{c|}{$\begin{array}{c}\mathrm{t} \\
\text { value }\end{array}$} & \multicolumn{1}{c|}{$\begin{array}{c}\mathrm{P} \\
\text { value }\end{array}$} \\
\cline { 2 - 3 } & $\begin{array}{c}\text { Govt } \\
\text { school }\end{array}$ & $\begin{array}{c}\text { Private } \\
\text { school }\end{array}$ & \\
\hline 5 & $104.52 \pm 5.9$ & $111.39 \pm 1.6$ & 6.080 & 0.001 \\
\hline 6 & $109.56 \pm 5.35$ & $117.16 \pm 1.70$ & 7.415 & 0.001 \\
\hline 7 & $110.32 \pm 6.44$ & $121.46 \pm 2.17$ & 8.97 & 0.001 \\
\hline 8 & $113.99 \pm 7.73$ & $126.61 \pm 3.09$ & 8.292 & 0.001 \\
\hline 9 & $118.22 \pm 6.34$ & $134.00 \pm 2.49$ & 12.67 & 0.001 \\
\hline 10 & $128.86 \pm 8.59$ & $138.96 \pm 2.14$ & 6.248 & 0.001 \\
\hline
\end{tabular}

As shown in Table 3, the mean weight of the private school was increased from $18.46 \mathrm{~kg}$ to $29.70 \mathrm{~kg}$ and the mean weight of government school was increased from $15.20 \mathrm{~kg}$ to $23.10 \mathrm{~kg}$. The mean weight of private school was found to 
be more than mean weight of government school in each age group. Results found to be statistically highly significant.

Table 3: Comparison of weight (in $\mathrm{kgs}$ ) of Govt and Private School children

\begin{tabular}{|l|l|l|l|l|}
\hline \multirow{2}{*}{$\begin{array}{l}\text { Age in } \\
\text { years }\end{array}$} & \multicolumn{2}{|l|}{$\begin{array}{l}\text { Weight of children ( mean } \\
\pm \text { SD) }\end{array}$} & t value & $\begin{array}{l}\text { P } \\
\text { value }\end{array}$ \\
\cline { 2 - 5 } Govt school & $\begin{array}{l}\text { Private } \\
\text { school }\end{array}$ & & \\
\hline 5 & $15.20 \pm 1.29$ & $18.46 \pm 1.20$ & 10.103 & 0.001 \\
\hline 6 & $15.20 \pm 1.49$ & $19.70 \pm 1.76$ & 10.658 & 0.001 \\
\hline 7 & $15.0 \pm 1.51$ & $21.49 \pm 2.40$ & 12.526 & 0.001 \\
\hline 8 & $16.77 \pm 2.42$ & $25.47 \pm 1.55$ & 16.605 & 0.001 \\
\hline 9 & $20.90 \pm 1.75$ & $28.10 \pm 1.49$ & 17.147 & 0.001 \\
\hline 10 & $23.10 \pm 2.18$ & $29.70 \pm 2.34$ & 11.296 & 0.001 \\
\hline
\end{tabular}

As shown in Table 4, the mean body mass index of the private school was increased from16.86 to 21.44 and the mean body mass index of government school was increased from 13.70 to 18.38. The mean body mass index of private school was found to be more than the mean body mass index of government school in each age group. Results found to be statistically highly significant.

Table 4: Comparison of BMI of Govt and Private School children

\begin{tabular}{|l|l|l|l|l|}
\hline \multirow{2}{*}{$\begin{array}{l}\text { Age in } \\
\text { years }\end{array}$} & \multicolumn{2}{|l|}{$\begin{array}{l}\text { BMI of children ( mean } \\
\pm \text { SD) }\end{array}$} & $\begin{array}{c}\mathrm{t} \\
\text { value }\end{array}$ & $\begin{array}{c}\mathrm{P} \\
\text { value }\end{array}$ \\
\cline { 2 - 4 } $\begin{array}{l}\text { Govt } \\
\text { school }\end{array}$ & $\begin{array}{c}\text { Private } \\
\text { school }\end{array}$ & & \\
\hline 5 & $13.70 \pm 1.27$ & $16.86 \pm 1.06$ & 10.418 & 0.001 \\
\hline 6 & $13.89 \pm 1.42$ & $17.05 \pm 1.51$ & 8.338 & 0.001 \\
\hline 7 & $14.49 \pm 1.44$ & $17.83 \pm 1.99$ & 7.426 & 0.001 \\
\hline 8 & $15.49 \pm 2.29$ & $20.14 \pm 1.22$ & 9.825 & 0.001 \\
\hline 9 & $17.95 \pm 1.53$ & $20.92 \pm 1.33$ & 8.017 & 0.001 \\
\hline 10 & $18.38 \pm 1.95$ & $21.44 \pm 1.68$ & 6.503 & 0.001 \\
\hline
\end{tabular}

As shown in Table 5, the mean chest circumference of the private school was increased from $46.91 \mathrm{~cm}$ to $49.96 \mathrm{~cm}$ and the mean chest circumference of government school was increased from $43.36 \mathrm{~cm}$ to $48.94 \mathrm{~cm}$. The mean body mass index of private school was found to be more than the mean body mass index of government school in each age group.

Table 5: Comparison of Chest Circumference of Govt and Private School Children

\begin{tabular}{|c|l|l|l|l|}
\hline \multirow{2}{*}{$\begin{array}{c}\text { Age in } \\
\text { yrs }\end{array}$} & \multicolumn{2}{|c|}{$\begin{array}{l}\text { Chest Circumferenceof } \\
\text { children (mean } \pm \text { SD) }\end{array}$} & \multirow{2}{*}{$\begin{array}{c}\text { t } \\
\text { value }\end{array}$} & $\begin{array}{c}\mathrm{P} \\
\text { value }\end{array}$ \\
\cline { 2 - 4 } & Govt school & $\begin{array}{l}\text { Private } \\
\text { school }\end{array}$ & \\
\hline 5 & $43.36 \pm 2.58$ & $46.91 \pm 1.87$ & 6.097 & 0.001 \\
\hline 6 & $45.52 \pm 4.15$ & $49.23 \pm 1.07$ & 4.739 & 0.001 \\
\hline 7 & $42.61 \pm 12.64$ & $48.66 \pm 1.73$ & 2.594 & 0.01 \\
\hline 8 & $48.41 \pm 3.71$ & $50.65 \pm 2.37$ & 2.788 & 0.007 \\
\hline 9 & $46.28 \pm 3.44$ & $49.8 \pm 2.79$ & 4.353 & 0.001 \\
\hline 10 & $48.94 \pm 2.61$ & $49.96 \pm 2.41$ & 1.570 & 0.122 \\
\hline
\end{tabular}

\section{Discussion}

The data we have presented here document a disturbing picture of under nutrition among the school children in government school. Our findings confirm the great magnitude of under nutrition which, more than any other disability, continues to hamper the physical growth. Indeed, it is a major threat to their very survival. In the present study the prevalence of under nutrition was examined. The results showed statistically significant decrease in are height, weight, body mass index, chest circumference in government school children. The findings of our study coincides with findings of Sandeep $\mathrm{S}$. Malegaonkar ${ }^{(6)}$, C Hamer ${ }^{(7)}$, Vinicius J. B. Martins ${ }^{(8)}$, Mercedes de Onis ${ }^{(9)}$, Sherin Billy Abraham ${ }^{(10)}$, Jaya Muneshwar et al, ${ }^{(11)}$. Hence proving, prevalence of under nutrition is more in government schools compared to private schools. 


\section{Conclusion}

Currently, under nutrition is a prevalent condition among school children. Health education among parents, community and school teachers are equally important. Comprehensive school health programme providing training for peripheral health workers and teachers should be planned to address this problem. Nutrition education about locally available protein and micronutrient rich plants is particularly effective. Community awareness and interest are important. The extent of malnutrition can be countered by educating the parents with respect to the basic nutritional requirements of their children and encouraging them to consume locally available low cost nutritious foods. The findings of this study suggest that govt school children were found to be under nourished and necessary action should be taken to prevent future complications.

\section{Acknowledgements}

Authors would like to thank all the study participants whose cooperation was important for the completion of the study. Authors also thank the school authorities and Dept of Physiology of both Malla Reddy Institute of Medical Sciences, Hyderabad and Guntur Medical College, Guntur for their support throughout the study.

\section{Conflict of interest: None declared}

\section{References}

1. Onfs,M.De ,Monteiro.C,2 Akre.J,3 \& Clugston.G4The worldwide magnitude of protein-energy malnutrition: an overview from the WHO Global Database on Child GrowthBulletin of the World Health Organization,1993: 71 (6): 703-7121

2. Manikandan Krishnan, Rajalakshmi P.V, Kalaiselvi.K-A Study of Protein Energy Malnutrition in the School Girls of a Rural Population, Int.Journal of Nutrition, Pharmacology, Neurologiocal disesases,mayaugust 2012, vol2, issue 22
3. Santosh Kumar.A, Sunil Kumar. D, Ashok .N.C, Ragavendra swamy Koppad, Protein Energy Malnutrition And Its Association With Immunization Status and Common Morbidities Among 1-5 Year Aged Children In Southern Part of India, Mysore, Int J Cur Res Rev, Jan 2013 / Vol 05 (02)page105

4. Vinodk.paul, ArvindBagga. GhaiEssential pediatrics 8th edition page no - 95

5. Kliegman, Stanton, st.Geme, schor, Behrman. Nelson text book of Pediatrics, 19th edition, vol 1. Page no - 106

6. Sandeep S. MalegaonkarSanjay V. Khandekar, S. A. Jaweed, Comparative Study of Height, Weight and Chest Circumference among Children of Municipal Corporation School and Private School, Indian Medical Gazette - SEPTEMBER 2011

7. C Hamer, K Kvatum, D Jeffries and S Allen, Detection of severe protein-energy malnutrition by nurses in The Gambia, Arch Dis Child 2004;89:181-184. doi: 10.1136/adc.2002.022715

8. Vinicius J. B. Martins, Telma M. M. Toledo Florêncio , Luciane P. Grillo , Maria do Carmo P. Franco , Paula A. Martins , Ana Paula G. Clemente, Carla D. L. Santos,

9. Maria de Fatima A. Vieira and Ana Lydia Sawaya, Long-Lasting Effects of Under nutrition, Int. J. Environ. Res. Public Health 2011, 8, 1817-1846; ISSN 1660-4601

10. Mercedes de Onis and Monika Blössner, The World Health Organization Global Database on Child Growth and Malnutrition: methodology and applications, International Journal of Epidemiology 2003;32:518526DOI: 10.1093/ije/dyg099

11. Sherin Billy Abraham1, Ramesh Chand Chauhan, Muthu Rajesh, Anil Jacob Purty, Zile Singh, Nutritional status and various morbidities among school children of a coastal area in South India, pISSN 2320-6071 | eISSN 2320-al. Int J Res Med Sci. 2015 Mar;3(3):718-722 
12. Jaya Muneshwar, KhaledMohsinBadaam, Ahmed M, Shoeb S, Khan S, Prevalence Of Underweight Status Among Secondary School Male Children From Low Socioeconomic Status In Aurangabad Maharashtra: A Crossectional PilotStudy, International Journal of Basic and Applied Physiology 